\title{
Pengembangan Pembelajaran Kimia Larutan Berdasarkan Ilmu Pengetahuan dan Pengaruhnya Terhadap Hasil Belajar dan Minat Siswa di Kelas XI SMA
}

\author{
Ramlan Silaban ${ }^{\mathrm{a}, *}$, Freddy Tua Musa Panggabean ${ }^{\mathrm{a}}$, Sari Marcella Sitompul ${ }^{\mathrm{a}}$, Patricia \\ Rohana Septiana Simarmata ${ }^{\text {a }}$ Irving Yosafat Silaban ${ }^{\text {b }}$ \\ ${ }^{a}$ Program Studi Pendidikan Kimia, Universitas Negeri Medan, Medan \\ ${ }^{b}$ Program Ilmu kimia, Universitas Sumatera utara, Medan
}

*Alamat Korespondensi: drrsilabanmsi@yahoo.co.id

\section{Abstract:}

This study aims to obtain chemistry-based teaching materials for scientific literacy on buffer solution materials that meet BSNP criteria, and to the extent able to improve the chemistry learning outcomes of high school students. This type of research is the development of ADDIE research model carried out in class XI MIA SMA Parulian 1 Medan. The instruments used were test and non-test instruments that had fulfilled validity. The study was conducted in 2 stages, namely the manufacturing phase of teaching materials based on scientific literacy and the limited trial phase. The results of the study are (1), it has been obtained teaching materials Buffer Solution based on science literacy that meet BSNP standards namely content eligibility $=3.51$, presentation eligibility $=3.49$, Language eligibility $=3.64$, and feasibility of graphic $=3.69 .(2)$, the results of limited trials in learning indicate that the average value of student learning outcomes in experimental class I was 83.10 higher than experimental class II of 75.24. (3), the results of limited trials in learning showed that the average student interest in the experimental class I was 79.33 higher than in the experimental class II which was 69.45.

Key words:

teaching materials based on scientific literacy, learning outcomes, learning interest, buffer solutions

\begin{tabular}{rlrr}
\hline \hline PENDAHULUAN & lingkungannya & dalam & menghadapi \\
Literasi sains merupakan kemampuan & permasalahan kehidupan sehari-hari dan \\
untuk memahami sains, mengkomunikasikan & mengambil keputusan $\begin{array}{r}\text { berdasarkan } \\
\text { sains, serta menerapkan kemampuan sains }\end{array}$ & $\begin{array}{l}\text { pengetahuan sains yang telah dipahaminya } \\
\text { untuk memecahkan masalah (Yuliati, 2017). }\end{array}$ & (Wulandari dan Sholihin, 2016).
\end{tabular}

Literasi sains juga dapat diartikan sebagai kecakapan ilmiah untuk mampu mengidentifikasi pertanyaan, menjelaskan fenomena ilmiah, serta mengambil simpulan berdasar fakta, serta kemauan untuk terlibat dan peduli terhadap isu-isu yang terkait sains (Kemendikbud, 2017). Konsep literasi sains mengharapkan siswa untuk memiliki rasa kepedulian yang tinggi terhadap diri dan

OECD (Organization for Economic Cooperation and Development) merupakan organisasi internasional yang concern pada perkembangan dunia pendidikan internasional. OECD secara periodik melakukan Programme for International Student Assesstment (PISA) setiap tiga tahun sekali. Salah satu aspek yang dinilai pada program ini adalah literasi sains peserta didik 
(Asyhari dan Hartati, 2015). Level literasi sains siswa Indonesia yang diukur oleh PISA sampai saat ini menunjukkan kondisi yang memprihatinkan (Rahayu, 2017). Skor pencapaian siswa-siswi Indonesia melalui hasil tes dan evaluasi PISA 2015 untuk sains berada di peringkat 62 dengan skor 403 dari 70 negara yang dievaluasi (Ariningtyas, dkk., 2017). Dan berdasarkan wawancara yang dilalukan Rusilowati et al (2016), yang menyatakan bahwa siswa kurang memahami penerapan ilmu pengetahuan dan teknologi dalam kehidupan sehari-hari. Tingkat kemampuan literasi sains yang lebih rendah pada kategori ini menunjukkan kurangnya pengetahuan siswa dalam sains. Paramita, dkk., (2016), menyatakan bahwa rendahnya kemampuan literasi sains siswa di Indonesia dipengaruhi oleh pemilihan bahan ajar yang dipakai di sekolah.

Bahan ajar adalah segala bentuk bahan yang digunakan untuk membantu guru/instruktor dalam melaksanakan kegiatan belajar mengajar (Depdiknas, 2008). Dengan memakai bahan ajar, guru bisa menghemat waktu dalam mengajar, mengubah peran guru dari seorang pengajar menjadi seorang fasilitator, meningkatkan proses pembelajaran menjadi lebih efektif dan interaktif (Purwati dan Suhirman, 2017). Namun, proses pembelajaran di sekolah pada umumnya masih menggunakan bahan ajar berupa buku teks yang hanya bersifat informatif, pendidik hanya terpaku pada bahan-bahan ajar yang konvensional tanpa ada kreatifitas untuk mengembangkan bahan ajar tersebut secara inovatif, maka disarankan agar menggunakan buku yang lebih aplikatif dalam proses pembelajaran (Silaban, dkk., 2015). Menurut Situmorang (2013), buku ajar yang baik harus mampu memotivasi pembelajar dengan memanfaatkan hal-hal menarik seperti gambar, ilustrasi, contoh soal, memiliki materi yang mencukupi untuk mendukung pengajaran, dan dapat dipergunakan untuk mendukung kegiatan pemecahan masalah.

Hutabalian (2014) mengatakan, inovasi bahan ajar selain dapat dilakukan saat pembelajaran di kelas, juga dapat dilakukan dengan mengembangkan buku ajar yang digunakan dalam belajar kimia. Menurut Trianto (2011), bahan ajar dalam bentuk handout dapat membantu siswa dalam belajar secara mandiri di rumah sebelum pelajaran yang dilakukan di kelas. Handout biasanya dibuat untuk tujuan instruksional. Handout menjadikan pembelajaran "portable dan enduring" (mudah dibawa kemana-mana dan abadi) dan dapat memuat kembali informasi yang telah didapat siswa dan mengembangkan test bagi siswa.

Penelitian sebelumnya terkait pengembangan bahan ajar berbasis literasi sains dilakukan oleh Astuti, dkk., (2012), dari hasil penelitian dan pembahasan dapat disimpulkan bahwa indeks gain kelas eksperimen sebesar 0,55, sedangkan kelas kontrol sebesar 0,40. Begitu juga penelitian yang dilakukan oleh Susanti, dkk., (2015) dengan penelitian yang berjudul Pengembangan bahan ajar IPA berbasis literasi sains bertema listrik dalam kehidupan untuk kelas IX, uji keterbacaan bahan ajar diperoleh hasil rata-rata 76,60\%. Kemampuan literasi sains siswa kelas eksperimen 73,72\% dan tergolong memiliki kemampuan literasi sains sedangkan kelas kontrol 59,46\%. Peneliti selanjutnya dilakukan oleh Hidayani, dkk., (2016), yang mengembangkan bahan ajar berbasis literasi sains pada materi fluida statis, bahan ajar yang dikembangkan memiliki tingkat keterbacaan yang tinggi dengan skor rata-rata 90,39\%. Peningkatan kemampuan literasi sains siswa kelompok eksperimen lebih tinggi daripada kelompok kontrol. Hal ini menunjukkan bahwa bahan ajar berbasis literasi sains materi fluida statis dapat menaikkan kemampuan literasi sains siswa.

Berdasarkan hasil observasi yang dilakukan di SMA Swasta Parulian 1 Medan, diketahui bahwa minat belajar kimia siswa masih tergolong rendah, dilihat dari rendahnya respon siswa saat kegiatan belajar mengajar berlangsung. Begitu pula dengan kemampuan literasi sains siswa, yang masih tergolong rendah. Hal ini dilihat dari persentase ketuntasan hasil belajar kimia siswa yang lulus pada KKM di sekolah hanya mencapai $40 \%$. Padahal kimia bukanlah 
pelajaran yang baru bagi siswa, namun hasil analisis yang dilakukan oleh Nurhidayatullah dan Prodjosantoso (2018) juga menunjukkan bahwa siswa sering mengalami kesulitan pada pelajaran kimia pada pokok bahasan larutan penyangga, khususnya saat membedakan larutan mana yang berasal dari asam lemah dengan garamnya atau asam lemah berlebih dengan basa kuat dan biasanya dalam menentukan $\mathrm{pH}$ larutan siswa langsung memasukkan angka ke rumus tanpa memahami klasifikasi spesies asam, basa, dan garamnya. Faktor penyebab terjadinya miskonsepsi pada materi ini, yaitu kelengkapan konteks buku kimia pendukung proses pembelajaran tidak cukup, dalam buku bahasa yang digunakan terlalu sulit sehingga siswa dalam memahami konsep masih kurang. Tidak hanya dari buku, siswa juga menjadi salah satu faktor penyebab terjadinya miskonsepsi itu sendiri. Selama proses pembelajaran materi larutan penyangga, terdapat siswa yang tidak fokus memperhatikan guru yang sedang menjelaskan materi, sehingga dapat mengakibatkan siswa tidak sepenuhnya menangkap penjelasan guru dengan baik. Hal tersebut bisa saja terjadi jika pembelajaran di kelas membosankan sehingga siswa tidak memiliki minat belajar. Akibat minat belajar yang rendah, maka hasil belajar siswapun rendah juga.

\section{METODE}

Penelitian ini merupakan jenis penelitian pengembangan (Development Research) yang tahapannya dimodifikasi dari model ADDIE. Penelitian dilakukan melalui 5 tahap yakni analisis kebutuhan (Silaban, 2018); Desain dan pengembangan Bahan Ajar Kimia berbasis literasi sain, Implementasi dan Standarisasi sesuai BSNP, Penilaian oleh Ahli (guru dan dosen kimia), Ujicoba pembelajaran terbatas di 2 kelas eksperimen, sebagaimana dapat dilihat pada Gambar

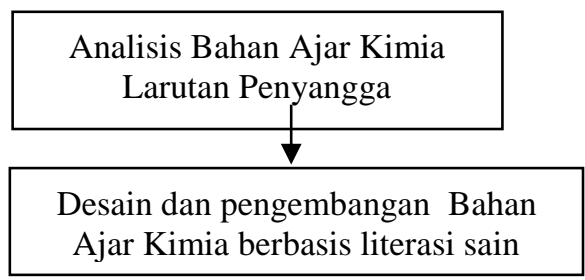

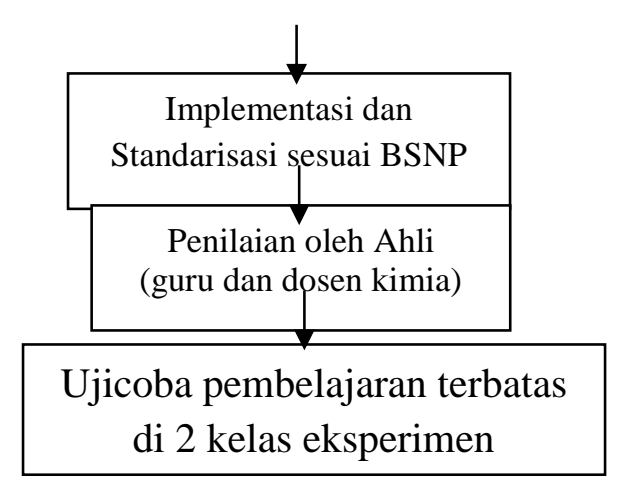

Gambar 1. Desain Rancangan dan Ujicoba Penelitian

Populasi dalam penelitian ini adalah seluruh siswa/i SMA Parulian 1 Medan sedangkan sampel penelitian adalah siswasiswi SMA kelas XI MIA dengan teknik pengambilan sampel yang digunakan adalah sampling total, dimana semua anggota populasi dijadikan sampel, dengan syarat sampel harus homogen. Desain penelitian yang digunakan untuk menguji keefektifan bahan ajar adalah menggunakan PretestPosttest Control Group Design. Instrumen yang digunakan adalah instrumen butir kelayakan merujuk indikator dari BSNP, instrumen penilaian produk oleh ahli, instrumen penilaian hasil belajar, instrumen penilaian minat belajar kimia.

Data yang diperoleh dari penilaian kelayakan bahan ajar dan minat belajar siswa diolah secara statistik deskriptif, yaitu dengan menghitung persentase jawaban responden, data hasil belajar diolah berdasar penilaian normatif, sementara untuk melihat adanya peningkatan dan atau hubungan antara hasil belajar dan minat, data diolah menggunakan analisis korelasi.

\section{HASIL DAN PEMBAHASAN}

Dari kelima tahapan penelitian, telah diperoleh beberapa data yang terkait dengan analisis kebutuhan, data kelayakan bahan ajar larutan penyangga berbasis literasi sain, data penilaian bahan ajar inovatif oleh ahli dan data hasil belajar dan minat belajar kimia siswa SMA. Produk yang diperoleh dari penelitian ini adalah bahan ajar kimia larutan penyangga berbasis literasi sain, hal mana setelah 
diujicobakan, ternyata mampu meningkatkan hasil belajar kimia dan minat belajar kimia siswa SMA. Uraian lebih detail atas hasil penelitian, dapat dilihat dalam paparan selanjutnya.

\section{Hasil analisis bahan ajar dalam Buku Teks Kimia}

Salah-satu kelemahan yang diamati siswa SMA saat ini adalah kurangnya minat baca terhadap literatur kimia khususnya yang berbau teks. Padahal, literasi sain menghendaki agar siswa banyak membaca teks dari berbagai sumber belajar. Salahsatu faktor yang menyebabkan kurangnya minat baca siswa adalah kurang nya variasi ilustrasi, gambar, teks, warna bahkan contoh konkret dalam kehidupan dalam buku bacaan, baik Buku Paket maupun buku teks lainnya.

Dari wawancara terhadap beberapa orang siswa dan guru menyatakan bahwa dalam pembelajaran kimia, termasuk Larutan penyangga, diperlukan suatu bahan ajar yang inovatif. Memang tidak dapat dipungkiri bahwa dalam pembelajaran Larutan Penyangga, nampaknya kurang diperlukan bahan bacaan yang rumit, melihat karakteristik materi ajar ini kebanyakan menyajikan rumus-rumus dan soal hitungan. Lagipula, para guru kimia umumnya seusai pembelajaran, lebih banyak memberikan tugas dalam bentuk soal-soal hitungan. Padahal, alangkah baiknya jika siswa diberi tugas untuk melakukan penelusuran kemanfaatan larutan penyangga itu dalam kehidupan manusia.

Para guru kimia juga menyatakan bahwa materi larutan penyangga akan lebih mudah difahami jika disertai dengan kegiatan praktikum. Melihat karakteristik materi ini yang memiliki kesamaan teori dengan materi hidrolisis, semestinya minat siswa akan lebih meningkat jika praktikum tersebut dimulai dari titrasi asam basa, namun karena keterbatasan fasilitas laboratorium, kegiatan praktikum sering terhambat.

Pelaksanaan penelitian terkait literasi sain ini, sangat didukung oleh sekolah tempat dilaksanakannya penelitian ini. Pihak Yayasan menyadari bahwa rendahnya mutu pembelajaran sekolah saat ini adalah disebabkan rendahnya literasi sain. Untuk itulah, dalam pengelolaan pembelajaran di SMA Parulian 1 Medan, untuk semua bidang studi, aspek literasi menjadi perhatian utama bahkan dijadikan sebagai ajang kompetisi antar siswa sekali dlaam setahun.

\section{Karakteristik dan Kelayakan Bahan Ajar Kimia Larutan Penyangga Berbasis Literasi Sains.}

Bahan ajar yang dikembangkan merupakan bahan ajar berbasis literasi sains didalamnya hanya membahas materi larutan penyangga yang dikembangkan dengan memperhatikan komponen literasi sains. Literasi sains dalam bahan ajar tersebut adalah sains sebagai batang tubuh pengetahuan ( $a$ body of knowledge) yaitu seluruh materi yang disajikan dalam bahan ajar, sains sebagai cara untuk menyelidiki (way of investigating) yang diwakili oleh bagian "Mencoba Yuk", sains sebagai cara untuk berpikir (a way of thinking) yang diwakili oleh bagian "Ayo Berpikir", dan interaksi antara sains, teknologi, dan masyarakat (interaction of science, technology, and society) yang diwakili oleh bagian "Kimia dalam Kehidupan". Gambar tiap aspek literasi sains dari bahan ajar berbasis literasi sains disajikan dalam Gambar 2. Sementara itu, bahan ajar lengkap yang dihasilkan, dapat dilihat pada dokumen laporan hasil penelitian yang ditulis secara lengkap.

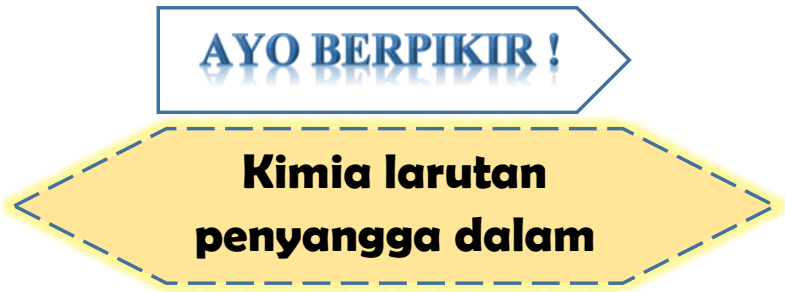

Gambar 2. Bagian-bagian dari bahan ajar yang Mewakili Tiap Aspek Literasi Sains

\section{Hasil uji kelayakan bahan ajar merujuk indikator BSNP. \\ Uji kelayakan dilakukan} menggunakan angket kelayakan berdasarkan Badan Standar Nasional Pendidikan (BSNP) yakni aspek kelayakan isi, kelayakan 
penyajian, kelayakan bahasa, kelayakan kegrafisan dan literasi sains.

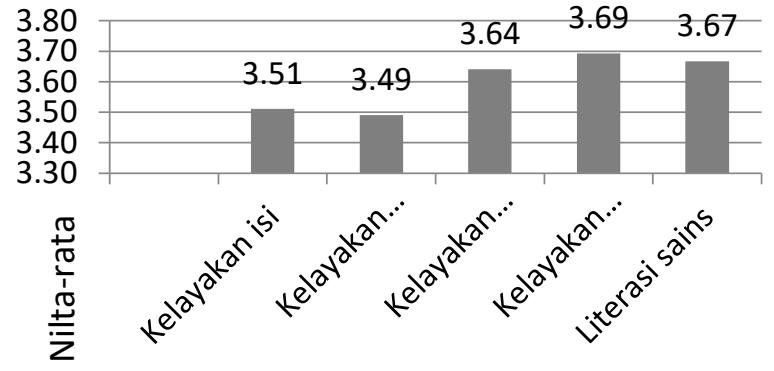

Gambar 3. Bahan Ajar Sesuai Standard BSNP

Penilaian kelayakan bahan ajar yang mengacu pada empat kategori literasi sains dapat dilihat pada gambar 4.

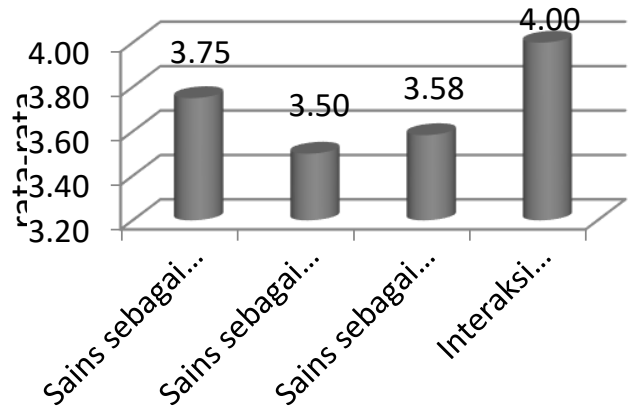

Gambar 4. Bahan Ajar Sesuai

Standard Literasi Sains

\section{Pengaruh Bahan Ajar inovatif terhadap} Hasil Belajar dan Minat Belajar siswa.

Pada awal penelitian, masing-masing kelas diberikan pretest untuk mengetahui kehomogenan kedua kelompok sampel di kelas eksperimen I dan kelas eksperimen II. Dari hasil pretest diperoleh hasil belajar siswa pada kelompok sampel di kelas eksperimen I yaitu dengan rata-rata 26,190 sementara siswa pada kelompok sampel di kelas eksperimen II yaitu dengan rata-rata 24,286. Hasil pretest diatas menunjukan bahwa kedua kelas memiliki kemampuan awal yang hampir sama karena hanya sedikit perbedaan pada kedua rata-rata kelas tersebut dan setelah dilakukan uji normalitas dan homogenitas pada kedua kelompok sampel diperoleh bahwa kedua kelompok sampel tersebut berdistribusi normal dan homogen. Langkah yang selanjutnya adalah peneliti memberi bahan ajar yang berbeda pada masing-masing kelas. Pada kelas eksperimen I diberi bahan ajar berbasis literasi sains yaitu handout dan bahan ajar tanpa literasi sains. Setelah kegiatan pembelajaran selesai, kemudian siswa mengisi angket minat kemudian melakukan posttest untuk mengetahui hasil belajar. Dari hasil posttest didapat rata-rata nilai siswa kelas eksperimen I adalah 83,095 dengan persentase ketuntasan $100 \%$ dan ratarata nilai siswa pada kelas eksperimen II adalah 75,238 dengan persentase ketuntasan 90,48\%. Dari data di atas hasil analisis homogenitas diperoleh nilah $F_{\text {hitung }}$ sebesar 1,876, dikonsultasikan dengan harga $F_{\text {tabel }}$ yakni sebesar 2,12. $F_{\text {hitung }}<F_{\text {tabel, }}$ yang berarti bahwa varians data tersebut homogen. Pegujian hipotesisdalam penelitian ini memiliki fungsi melihat pengaruh bahan ajar berbasis literasi sains pada materi larutan penyangga. Berdasarkan tabel 4.6 perhitungan uji-t diperoleh $t_{\text {hitung sebesar } 3,70}$ dikonsultasikan dengan $t_{\text {tabel }}$ pada taraf signifikan 5\% dengan db $=40$ sebesar 2,021. Harga $t_{\text {hitung }}>\mathrm{t}_{\text {tabel, }}$ maka hipotesis nol (Ho) ditolak dan hipotesis alternatif (Ha) diterima, yang artinya terdapat pengaruh positif yang dihasilkan oleh beberapa faktor, yaitu berkembangnya kemampuan berpikir siswa dan sumber belajar yang inovatif. Hasil penelitian ini sesuai dengan penelitian sebelumnya yang dilakukan oleh Hidayani, dkk., (2016) yang mengembangkan bahan ajar berbasis literasi sains pada kelas eksperimen nilai rata-rata pretest 27,06 kemudian posttest 67,25 . Peneliti sebelumnya tidak memakai model pembelajaran atau media tambahan lainnya, sehingga hasil belajar yang diperoleh oleh peneliti lebih tinggi dari hasil belajar yang diperoleh peneliti sebelumnya. Qomaliyah, dkk., (2016) membuat model pembelajaran inkuiri terbimbing berbasis literasi sains, memperoleh rata-rata pretest sebesar 23,40 kemudian posttest sebesar 76,92 dengan persentase ketuntasan $64 \%$. Lalu Ariningtyas, dkk., (2017) mengembangkan bahan ajar LKS pada materi hidrolisis garam, siswa yang merespon positif bahan ajar sebesar 77,67\% yaitu pada kategori baik.

Penilaian terhadap minat siswa berdasarkan angket yang diisi oleh siswa sendiri, maka diperoleh data pada kelas 
eksperimen I sebesar 79,33 dan pada kelas eksperimen II sebesar 69,45. Minat siswa pada kelas eksperimen I yang dibelajarkan dengan bahan ajar berbasis literasi sains lebih tinggi dari kelas eksperimen II yang dibelajarkan dengan bahan ajar tanpa literasi sains. Selaras dengan hasil belajar yang diperoleh, hasil belajar kelas eksperimen I lebih tinggi dari hasil belajar kelas eksperimen II. Hal ini sesuai dengan Sirait (2016) yang menyatakan terdapat pengaruh yang sangat signifikan antara minat terhadap hasil belajar siswa. Lalu Azis (2016) yang meneliti tentang hubungan minat, motivasi dan sikap terhadap hasil belajar. Besarnya kontribusi minat terhadap hasil belajar sebesar 51,5\%

Pada hipotesis kedua dilakukan uji korelasi product momen pearson, dimana diperoleh korelasi yang didapat sebesar 0,50 > 0,433 ( $\mathrm{r}_{\text {hitung }}>\mathrm{r}_{\text {tabel }}$ ), maka hipotesis ini menunjukkan bahwa ada hubungan positif yang signifikan antara minat belajar dengan hasil belajar siswa, (Ha) dapat diterima. Hal ini sesuai dengan Rozikin, dkk., (2018) yang menunjukan bahwa ada hubungan positif yang signifikan antara minat belajar dengan hasil belajar siswa sebesar 0,874 . Untuk hasil belajar pada penelitian ini, peneliti tidak mencantumkan nilainya, hanya menyimpulkan bahwa minat untuk belajar kimia siswa tinggi sehingga hasil belajar kimia yang diraih siswa juga tinggi. Keefektifan bahan ajar yang dikembangkan dapat dilihat dari kemampuan bahan ajar dalam meningkatkan minat dan kemampuan literasi sains siswa. Kemampuan literasi sains siswa dapat dilihat dari hasil belajar siswa. Hasil analisis pada kelas eksperimen I dan eksperimen II dapat dilihat dalam gambar 5.

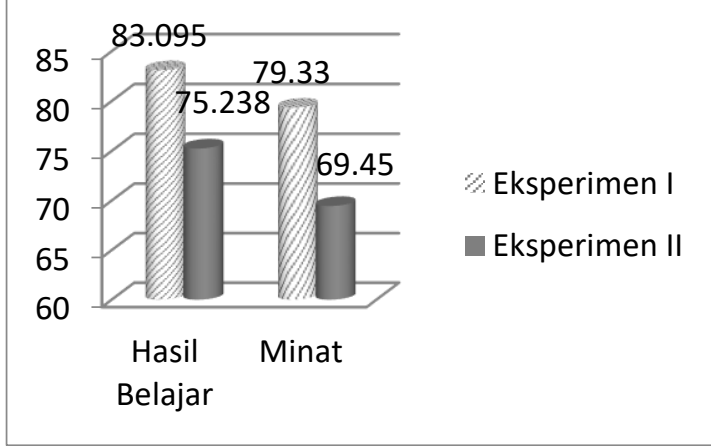

Gambar 5. Nilai Rata-Rata Hasil Belajar Dan Rata-Rata Minat Siswa

\section{Kesimpulan}

Berdasarkan uraian di atas, dapat diperoleh kesimpulan :

1. Pada pembelajaran kimia larutan penyangga di SMA, diperlukan bahan ajar inovatif sebagai pendamping buku teks dan sumber belajar lainnya

2. Berdasarkan hasil penilaian dosen dan guru kimia diperoleh bahan ajar handout berbasis literasi sains pada pokok bahasan larutan penyangga yang dikembangkan memenuhi kriteria BSNP, dengan data yang diperoleh Kelayakan Isi $=3,51$; Kelayakan Penyajian = 3,49; kelayakan Bahasan = 3,64; Kelayakan kegrafisan $=3,69$ dan untuk keseluruhan aspek literasi sains $=$ 3,67 .

3. Hasil belajar pada kelas eksperimen I memperoleh persentase ketuntasan sebesar $100 \%$ dengan nilai yang paling rendah adalah 70 dan tertinggi 95 . Pada kelas eksperimen II persentase ketuntasan sebesar 90,48\% dengan nilai yang paling rendah 60 dan tertinggi 95 .

4. Hasil belajar siswa yang dibelajarkan dengan bahan ajar berbasis literasi sains lebih tinggi secara signifikan dari hasil belajar siswa yang diajarkan dengan bahan ajar tanpa literasi sains. Hasil belajar siswa pada kelas eksperimen I sebesar 83,10 lebih besar daripada hasil belajar siswa pada kelas eksperimen II sebesar 75,24.

5. Terdapat korelasi positif yang signifikan antara minat dan hasil belajar siswa yang dibelajarkan menggunakan bahan ajar berbasis literasi sains $\left(r_{x y}=\right.$ $\left.0,50>\mathrm{r}_{\text {tabel }}=0,433\right)$.

\section{Daftar Pustaka}

Ariningtyas, A., Wardani, S., dan Mahatmanti, W., (2017), Efektivias Lembar Kerja Siswa Bermuatan Etnosains Materi Hidrolisis Garam untuk Meningkatkan Literasi Sains Siswa SMA, Journal of Innovative Science Education, 6(2):187-196.

Astuti, W. P., Prasetyo, A. P. B., dan Rahayu, E. S., (2012), Pengembangan 
Ramlan Silaban, Freddy Tua Musa Panggabean, Sari Marcella Sitompul, Patricia Rohana Simarmata, Irving Silaban / Jurnal Inovasi Pembelajaran Kimia (Journal Of Innovation in Chemistry Education) Volume. 1, No.2, Oktober 2019 Pengembangan Pembelajaran Kimia Larutan Berdasarkan Ilmu Pengetahuan dan Pengaruhnya Terhadap Hasil Belajar dan Minat Siswa di Kelas XI SMA

Instrumen Asesmen Autentik Berbasis Literasi Sains Pada Materi Sistem Ekskresi, Lembaran Ilmu Kependidikan, 41(1) : 39-43

Asyhari, A. dan Hartati, R., (2015), Profil

Peningkatan Kemampuan Literasi Sains Siswa Melalui Pembelajaran Saintifik, Jurnal Ilmiah Pendidikan Fisika, 4(2) : 179-191.

Depdiknas, (2008), Panduan Pengembangan Bahan Ajar, Direktorat Jenderal Manajemen Pendidikan Dasar Dan Menengah, Jakarta.

Hidayani, F., Rusilowati, A., Masturi, (2016), Pengembangan Bahan Ajar Berbasis Literasi Sains Materi Fluida Statis, Unnes Physics Education Journal, 5(3) : 25-31

Hutabalian, T., (2014), Pengembangan Buku Ajar Kimia Inovatif Kelas X SMA Semester I Sesuai Kurikulum 2013, Tesis, FMIPA, Universitas Negeri Medan, Medan.

Kemendikbud, (2017), Materi Pendukung Literasi Sains, Kemendikbud, Jakarta.

Nurhidayatullah, N. dan Prodjosantoso, A. K., (2018), Miskonsepsi Materi Larutan Penyangga, Jurnal Inovasi Pendidikan IPA, 4(1) : 41-51.

OECD, (2013), PISA 2012 Assassement and Analytical Framework: Mathematics, Reading, Science, Problem Solving and Financial Literacy. Diakses dari http://www.oecd.org.

Purwati, D., dan Suhirman, (2017), Pengembangan Bahan Ajar Perkuliahan Apresiasi Sastra Anak Berbasis Sugesti-Imajinatif Untuk Mengoptimalkan Budaya Menulis Mahasiswa Pada Program Studi Pendidikan Guru Sekolah Dasar (PGSD), Jurnal Ilmiah Mandala Education, 3(1) : 166-174.

Rahayu, S., Mengoptimalkan Aspek Literasi Dalam Pembelajaran Kimia Abad 21, Prosiding Seminar Nasional Kimia UNY 2017.

Ratnawati, E., Rahayu, S., dan Fajaroh, F., (2016), Pengaruh Learning Cycle-5E Berkonteks SSI Terhadap Pemahaman
Hakikat Sains Pada Materi Larutan Penyangga dan Hidrolisis Garam Siswa SMA, Jurnal Pendidikan Sains, 4(1) : 25-35.

Rusilowati, A., Kurniawati, L., Nugroho, S. E., dan Widiyatmoko, A., (2016), Developing an Instrument of Scientific Literacy Asessment on The Cycle Theme, International Journal of Environmental \& Science Education, 11(12) : 5718-5727.

Silaban, R., Tarigan, R., Alexander, I.J. (2018); Analisis hasil belajar kimia siswa yang dibelajarkan menggunakan model PBL bermedia Powerpoin melalui pendekatan Saintifik pada Pokok Bahasan Redoks; Jurnal Ilmu Pendidikan Indonesia, 6 (3); 110-119.

Silaban, R., Septiani, B., dan Hutabarat, W., (2015), Penyusunan Bahan Ajar Kimia Inovatif Materi Laju Reaksi Terintegrasi Pendidikan Karakter Siswa SMA, Jurnal Tabularasa PPS Unimed, 12(1) : 78-88.

Situmorang, M., (2013), Pengembangan Buku Ajar Kimia SMA Melalui Inovasi Pembelajaran dan Integrasi Pendidikan Karakter Untuk Meningkatkan Hasil Belajar Siswa, Prosiding Semirata FMIPA Universitas Lampung 2013.

Susanti, M., Rusilowati, A., dan Susanto, H., (2015), Pengembangan Bahan Ajar IPA Berbasis Listrik Dalam Kehidupan Untuk Kelas IX, Unnes Physics Education Journal, 4(3) : 4349.

Trianto, (2011), Mendesain Model Pembelajaran Inovatif-Progresif, Kencana, Jakarta.

Wulandari, N. dan Sholihin, H., (2016), Analisis Kemampuan Literasi Sains Pada Aspek Pengetahuan dan Kompetensi Sains Siswa SMP Pada Materi Kalor, Edusains, 8 (1) : 66-73. Yuliati, Y., (2017), Literasi Sains Dalam Pembelajaran IPA, Jurnal Cakrawala Pendas, 3 (2) : 21-28. 